\title{
Membangun Dialog Peradaban
}

\author{
Zaprulkhan \\ Fakultas Dakwah \\ STAIN Syaikh Abdurrahman Siddik Bangka Belitung \\ Bangka, Indonesia \\ zaprulkhan_zahra@yahoo.co.id
}

\begin{abstract}
In 1989 Francis Fukuyama with his article The End of History? In the journal The National Interest revolves a speculative thesis that after the West conquered its ideological rival, hereditary monarchy, fascism and communism, the constellation of the world of international politics reached a remarkable consensus to liberal democracy. A few years later, Samuel P. Huntington came up with a more provocative thesis that ideological-based war would be a civilization-based war in his article, The Clash of Civilizations? In the journal Foreign Affairs. It reveals that in the future the world will be shaped by interactions among the seven or eight major civilizations of Western civilization: Confucius, Japan, Islam, Hinduism, Orthodox Slavs, Latin America and possibly Africa. Huntington directed the West to pay particular attention to Islam, for Islam is the only civilization with great potential to shake Western civilization. Departing from the above hypotheses, this paper will specifically discuss the bias of Fukuyama and Huntington's thesis on Islam, and how its solution to build a dialogue of civilization by taking the paradigm of dialogue from Ibn Rushd and Raghib As-Sirjani.
\end{abstract}

Keywords: building, dialogue of civilizations, the west, Islam

\section{Abstrak}

Pada tahun 1989 Francis Fukuyama dengan artikelnya The End of History? Dalam jurnal The National Interest revolusioner tesis spekulatif bahwa setelah Barat telah menaklukkan lawan-lawan ideologisnya, monarki herediter, fasisme dan komunisme, konstelasi politik internasional mencapai konsensus yang luar biasa untuk demokrasi liberal. Beberapa tahun kemudian, Samuel P. Huntington muncul dengan tesis yang lebih provokatif bahwa perang berbasis ideologis akan menjadi perang berbasis peradaban dalam artikelnya, The Clash of Civilisations? Dalam jurnal Luar Negeri. Ini mengungkapkan bahwa di masa depan akan dibentuk oleh interaksi antara tujuh atau delapan peradaban utama peradaban Barat: Konfusius, Jepang, Islam, Hindu, Slavia Ortodoks, Amerika Latin dan mungkin Afrika. Perhatian Huntington pada Islam adalah potensi terpenting untuk mengguncang peradaban Barat. Berangkat dari hipotesis di atas, makalah ini akan secara khusus membahas bias tesis Fukuyama dan Huntington tentang Islam, dan bagaimana mereka akan mengambil paradigma dialog dari Ibn Rushd dan Raghib As-Sirjani.

Kata kunci: bangunan, dialog peradaban, barat, Islam

\section{A. Prolog}

Pada tahun1989 Francis Fukuyama dengan artikelnya The End of History? di jurnal The

National Interest menggulirkan tesis spekulatif tentang masa depan politik


global. Dalam makalahnya itu, Fukuyama mencatat bahwa setelah Barat menaklukkan rival ideologisnya, monarki herediter, fasisme dan komunisme, konstelasi dunia politik internasional mencapai satu konsensus yang luar biasa terhadap demokrasi liberal. Ia berasumsi bahwa demokrasi liberal adalah semacam titik akhir dari evolusi ideologis atau bentuk final dari pemerintahan. Bersama berakhirnya perang ideologi, dengan kalahnya blok komunis, telah memberi tempat tertinggi kepada negeri kampiun demokrasi Amerika sebagai The Last Man.

Itu artinya demokrasi liberal yang dijajakan oleh Amerika tidak memiliki saingan lagi di pasaran internasional. Fenomena ini menjadi sebuah 'akhir sejarah' (the end of history). Artikel tersebut kemudian dieksplorasi lebih luas menjadi sebuah buku: The End of History and The Last Man. ${ }^{1}$ Fukuyama memasang sederet negara yang pada tahun 1990-an memilih sistem demokrasi liberal, sehingga ini seolah-olah menjadi indikasi, bahwa - sesuai ramalan Hegelmaka akhir sejarah umat manusia adalah kesepakatan mereka untuk menerima demokrasi liberal. Tahun 1790, hanya tiga negara, Amerika Serikat, Swiss dan Prancis, yang memilih demokrasi liberal. Tahun 1848, jumlahnya menjadi lima negara; tahun 1900, 13 negara; tahun1919, 25 negara; tahun 1940, 13 negara; tahun 1960, 36 negara; tahun 1975, 30 negara dan tahun 1990, 61 negara. Pada akhir sejarah, menurut Fukuyama, tidak ada lagi tantangan ideologis yang serius terhadap demokrasi liberal, kecuali dunia Islam. ${ }^{2}$

Dua tahun kemudian, pada tahun 1991, Barry Buzan menggagas tesis konflik ideologis antara kekuatan Barat dan kekuatan Timur, khususnya antara Barat dengan Islam yang melahirkan perang dingin. Menurut Buzan, dalam kasus Islam, ancaman ini diperdalam dengan kedekatan geografis dan antagonisme historis dan juga peranan politik terbuka yang dimainkan oleh Islam dalam kehidupan para pengikutnya Persaingan dengan Barat menjadi lebih potensial dengan fakta bahwa Islam sendiri masih merupakan identitas kolektif yang ketat dan berkembang. $^{3}$

Dalam durasi waktu yang sama, dua tahun sesudahnya, Samuel P. Huntington tampil dengan tesis spekulatif yang lebih menggigit bahwa perang berbasis ideologis akan menjelma menjadi perang berbasis peradaban dalam artikelnya, The Clash of Civilizations? di jurnal Foreign Affairs. Artikel tersebut kemudian dikembangkan menjadi sebuah buku: The Clash of

\footnotetext{
${ }^{1}$ Mengenai kajian perang ideologis ini secara detail dapat dilihat dalam Francis Fukuyama, The End of History and The Last Man, Terj. M. HLM. Amrullah (Yogyakarta: Qalam, 2004); Mengenai buku Fukuyama tersebut telah dicounter secara spesifik dan luas oleh Murad W. Hofmann dengan bukunya Islam: The Alternative, terj. Rahmani Astuti (Bandung: Pustaka Hidayah, 2002).

${ }^{2}$ Adian Husaini, Wajah Peradaban Barat (Jakarta: Gema Insani Press, 2005), hlm. 80-81.

3 John L. Esposito (eds.), Dialektika Peradaban. Terj. Ahmad Syahidah (yogyakarta: Qalam, 2002), hlm. 87-88.
} 
Civilization and The Remaking of World Order. Menurut Huntington benturan antar peradaban akan mendominasi politik global.

Ia mengungkapkan bahwa identitas peradaban akan semakin penting pada masa akan datang dan dunia akan dibentuk dalam ukuran besar oleh interaksi diantara tujuh atau delapan peradaban utama. Peradaban ini meliputi peradaban Barat, Konfusius, Jepang, Islam, Hindu, Slavia Ortodoks, Amerika Latin dan mungkin Afrika. Konflik yang paling penting pada masa akan datang terjadi di antara garis budaya yang memisahkan satu peradaban dengan yang lain. ${ }^{4}$ Huntington mengarahkan Barat untuk memberi perhatian khusus kepada Islam, karena di antara berbagai peradaban besar yang masih eksis hingga kini, hanya Islamlah satu-satunya peradaban yang berpotensi besar menggoncang peradaban Barat. Tema clash of civilization kemudian menjadi paling populer dan menjadi kenyataan dalam kebijakan politik internasional. ${ }^{5}$

Jika tesis Barry Buzan tidak mengantarkan namanya dikenal dalam konstelasi dunia, Francis Fukuyama dengan tesis perang ideologisnya dan terlebih lagi Samuel Huntington dengan tesis benturan antar peradaban yang dikemas dengan bahasa yang provokatif menempatkan keduanya sebagai ilmuwan terpopuler selama dekade 1990-an, menjelang akhir milenium ke-2. Berangkat dari hipotesis-hipotesis di atas, tulisan ini secara spesifik akan menyoroti bias-bias tesis Fukuyama dan Huntington terhadap Islam, serta bagaimana solusinya untuk menciptakan dialog peradaban, bukan benturan peradaban.

\section{B. Relasi Islam Dengan Demokrasi}

Tesis besar Fukuyama yang menyatakan bahwa demokrasi liberal akan menjadi fenomena global kecuali Islam yang tidak kompatibel dengan demokrasi, tentu saja sangat debatable dan questionable. Terlepas dari kelemahan internal tesis ini, kenyataannya memang demokrasi tidak kompatibel atau belum juga doesn't work di negara-negara Muslim. Munurut tinjauan para ahli, setidaknya ada tiga variabel penghambat praktek demokrasi: pemahaman doktrinal yang rigid, kultur dunia Islam yang sudah terbiasa dengan otokrasi dan ketaatan pasif, dan butuhnya pengalaman atau waktu. ${ }^{6}$

Padahal para ilmuwan Muslim telah menggagas bagaimana pola-pola hubungan Islam dengan demokrasi. ${ }^{7}$ Pertama, analisis yang mengklaim bahwa Islam tidak bisa dipisahkan

\footnotetext{
${ }^{4}$ Untuk perbincangan berbagai peradaban ini lebih luas bisa dilihat dalam Samuel P. Huntington, Benturan Antar Peradaban dan Masa Depan Politik Dunia. Terj. M. Sadat Ismail (Yogyakarta: Qalam, 2005), hlm. 47-52.

${ }^{5}$ Huseini, Wajah Peradaban..., hlm. 131.

${ }^{6}$ Mun'im A. Sirry, Dilema Islam Dilema Demokrasi (Jakarta: Gugus Press, 2002), hlm. 119120.

${ }^{7}$ Sebenarnya pola-pola ini bukan hanya ada dalam Islam tapi juga ada pada agama Yahudi \& Kristen. Lihat Komaruddin Hidayat, Tragedi Raja Midas (Jakarta: Paramadina, 1998), hlm. 9-22.
} 
dengan negara. Ini artinya Islam mendukung demokrasi seutuhnya. Kendati keduanya menempati ruang berbeda, Islam dan negara saling terkait. Islam mencakup din, dunya, dan daulah - agama, dunia dan negara. Bahkan para pendukung pola ini mengidentikkan demokrasi dengan syura atau prinsip musyawarah. Namun di sini harus dilihat secara kritis dan objektif bila musyawarah tidak sama dengan demokrasi. Sebab demokrasi dalam pengertian modern meliputi nation-state, multi partai, mekanisme pemilu, berapa lama kekuasaan harus dijabat, pembagian kekuasaan, peralihan kekuasaan secara rasional, dan melibatkan partisipasi rakyat banyak. Sedangkan musyawarah hanya bagian dari variabel-variabel tersebut. ${ }^{8}$

Kedua, analisis yang meneguhkan bahwa agama dan negara itu terpisah, tidak dapat dicampuradukkan. Ini konsep memahami dan mengelola kehidupan negara hasil adopsi Barat yang juga mempunyai basis dalam Islam. Model ini menekankan seluruh urusan publik harus diatur secara rasional dan sekuler, sementara agama dianggap berada dalam domain privat. Karenanya, agama tidak dapat ikut campur secara legal atau formal dalam proses politik.

Ketiga, arus pemikiran yang cukup unik karena menegaskan bahwa agama dan negara saling tumpang tindih. Konsep ini berasumsi bahwa Islam memang tidak mencakup segalagalanya, tapi mencakup seperangkat prinsip dan tata nilai etika tentang kehidupan bermasyarakat, dalam hal ini termasuk persoalan demokrasi. ${ }^{9}$ Ketiga pola demokrasi Islam ini, sesungguhnya cukup memadai bagi perpolitikan Islam. Namun harus diakui hingga hari ini, semua konsep itu belum teraplikasikan secara komprehensif dalam wilayah negara mayoritas Muslim.

Walaupun demikian, adalah cukup beralasan bila kaum Muslim mengembangkan prinsip-prinsip demokrasi yang sesuai dengan konstelasi dunia Islam, tidak harus identik secara mutlak dengan demokrasi Barat. Dalam konteks ini, menarik untuk menengok sekilas studi kritis-komparatif John L. Esposito dan John O. Voll terhadap eksperimentasi kaum Muslim dalam berdemokrasi di Aljazair, Mesir, Iran, Malaysia, Pakistan dan Sudan. Keenam negara Muslim tersebut, menurut kedua Islamisis abad kotemporer ini, pada level tertentu tetap

\footnotetext{
${ }^{8}$ Komaruddin Hidayat, Wahyu Di Langit Wahyu Di Bumi (Jakarta: Paramadia, 2003), hlm. 55 \& 103.

${ }^{9}$ Persoalan ini banyak dibahas dalam buku-buku yang berbicara mengenai demokrasi atau politik Islam, seperti Munawir Sjazali, Islam dan Tata Negara (Jakarta: UI Press, 1993), hlm. 1-2; Suyuthi Pulungan, Fiqh Siyasah (Jakarta: Grafindo Persada, 2002), hlm. X; Tim Puslit IAIN Syaruf Hidayatullah, Pendidikan Kewarganegaraan, Demokrasi, HAM \& Masyrakat Madani (Jakarta: IAIN Press, 2000), hlm. 127-128; Bandingkan dengan Mun'im A. Sirry, Membendung Militansi Agama (Jakarta: Erlangga, 2003), hlm. 76-78.
} 
mengaplikasikan prinsip-prinsip demokrasi yang khas dengan konteks dan identitas bangsa mereka masing-masing. ${ }^{10}$

Amerika sebagai polisi dunia tidak berhak memaksakan demokrasi mereka kepada negara lain. "Sama sekali mustahil bagi masyarakat yang berada ribuan mil jauhnya dari dunia atlantik baik dalam ruang dan identitas dipaksa untuk menyesuaikan diri dengan apa yang kita inginkan dari mereka", demikian sinyalir afirmatif Edward W. Said terhadap kebijakan Barat yang ingin mendominasi dunia Islam. ${ }^{11}$

Kebijakan dominatif ini diakui secara jujur oleh Bryan S. Tuner, sosiolog kenamaan abad ini, bahwa dunia Islam digiring harus tunduk mutlak mengikuti konsep-konsep Barat. Pijakan fundamental formulasinya sangat transparan: I know the difference, therefore I control (aku tahu perbedaannya, karena itu aku mengontrolnya). ${ }^{12}$ Jadi tidak bisa dibenarkan untuk searah dengan pandangan Barat secara absolut dan sampel kasuistiknya adalah protes yang dilakukan masyarakat dunia di Seatle pada November 1999 terhadap kebijakan WTO yang ingin menerapkan agenda sepihak Amerika Serikat. ${ }^{13}$

Menurut Kishore Mahbubani, pemberontakan atau tantangan terhadap dominasi kebijakan Amerika dalam segala aspeknya sudah mulai ditunjukkan oleh bangsa-bangsa Asia. Dengan bahasa yang sangat elegan dan provokatif-inspiratif, Mahbubani melukiskan bahwa meskipun sampai saat ini standard hidup yang lebih tinggi masih bertahan di Barat, namun orang-orang Asia tidak lagi menganggap Barat sebagai model utama masyarakat mereka. Mereka mulai yakin kalau bisa melakukan hal berbeda. Hari ini orang Asia memang masih bisa melihat puncak kesenangan yang dihuni sebagian besar masyarakat Barat, tapi mereka juga bisa melihat, di luar puncak itu, pilihan-pilihan alternatif yang bisa dijadikan model bagi masyarakat mereka sendiri.

Alih-alih melihat puncak kebijakan (kesenangan) itu sebagai tujuan akhir yang natural, mereka saat ini berkeinginan menghindarinya (karena mereka tidak ingin dibebani penyakitpenyakit sosial dan budaya yang menimpa masyarakat Barat) dan mencari jalan-jalan alternatif di luar jalur yang dilalui masyarakat Barat. Horizon ini tidak pernah eksis dalam mind orang

\footnotetext{
${ }^{10}$ Untuk pembahasan yang cukup elegan dan sangat inspiratif mengenai praktik demokrasi di keenam negara Muslim tersebut bisa dilihat dalam John L. Esposito \& John O Voll, Demokrasi di Negara-Negara Muslim. Terj. Rahmani Astuti (Bandung: Mizan, 1999).

${ }^{11}$ Edward W. Said, Covering Islam. Terj. Asnawi \& Supriyanto Abdullah (Yogyakarta: Ikon Teralitera, 2002), hlm. 225.

12 Bryan S. Tuner, Runtuhnya Universalitas Sosiologi Barat. Terj. Sirojuddin Arif dkk. (Yogyakarta: Ar-Ruzz, 2002), hlm. 114.

${ }^{13}$ William K. Tabb, Tabir Politik Globalisasi. Terj. Uzair Fauzan dkk. (Yogyakarta: Lafald Pustaka, 2003), hlm. 1-2.
} 
Asia sampai saat ini. Fenomena ini memunculkan konfedensi baru orang Asia dalam diri mereka sendiri. ${ }^{14}$

Ada kesadaran yang tengah berkembang dalam pikiran mereka bahwa masyarakat mereka, seperti masyarakat Barat, memiliki warisan filsafat, budaya dan sosial yang kaya yang bisa dijadikan sandaran dan digunakan untuk mengembangkan masyarakat modern dan berkembang. Secara agak ekstrem, bahkan Mahbubani mengklaim bahwa awal milenium ketiga ini ketika pengaruh Eropa begitu cepat berakhir, pendulum masa depan menghadapkan wajahnya ke arah Pasifik, bukan Atlantik. ${ }^{15}$

Tesis Mahbubani ini bukan hanya bualan hampa atau gagasan utopis semata. Ide-ide yang ia bangun berdasarkan perbandingan fakta-fakta objektif antara dunia Barat dan Timur, sehingga ia menggulirkan tesis kebangkitan Asia sudah di ambang pintu atau sedang dimulai. Dengan alasan ini, mungkin buku tersebut menjadi buku Internasional Bestseller setelah The Clash of Civilization dan The End of History. ${ }^{16}$

Mungkin itu alasannya mengapa beberapa tahun kemudian, Fukuyama mengakui bahwa masyarakat Amerika sendiri mengalami krisis kepercayaan terhadap kebijakan universalnya. Mereka tidak lagi percaya secara total kepada kearifan-kearifan lokal budaya mereka yang diklaim mesti menjadi referensi universal seluruh warga dunia. ${ }^{17}$ Sungguh merupakan paradoks dan ironinya sebuah kepongahan intelektual sekaligus kekuasaan, sebab tesis yang diklaim universal ternyata dibantahnya sendiri.

\section{Benturan Antar Peradaban Atau Stereotip}

Kira-kira tiga belas tahun yang lalu, Samuel P. Huntington mengajukan tesisnya dengan kalimat yang tegas:

"Menurut hipotesis saya sumber utama konflik dunia baru tidak lagi ideologi atau ekonomi, melainkan budaya. Budaya akan memilah-milah manusia dan menjadi sumber konflik yang dominan. Negara-negara akan tetap menjadi aktor dalam percaturan dunia, tapi konflik politik global yang paling prinsipil akan terjadi antara bangsa-bangsa dan kelompok-kelompok karena peradaban mereka. Benturan peradaban akan mendominasi politik global." 18

\footnotetext{
${ }^{14}$ Kishore Mahbubani, Bisakah Orang Asia Berpikir? Terj. Salahuddien GZ (Bandung: Mizan, 2005), hlm. 15.

${ }^{15}$ Ibid., hlm. 163-194.

${ }^{16}$ Hal ini diekspos pada sampul depan dan belakang buku Mahbubani tersebut.

${ }^{17}$ Tesis kontradiktif ini dibahas cukup panjang dalam Francis Fukuyama, Trust Kebijakan Sosial \& Penciptaan Kemakmuran. Terj. Ruslani (Yogyakarta: Qalam, 2002), hlm. 395-468.

${ }^{18}$ Sirry, Dilema Islam ...., hlm. 242; Esposito, Dialektika Peradaban....., hlm. 88-89. 
Secara singkat, Huntington mengemukakan lima alasan pokok mengapa benturan peradaban akan menjadi sumber konflik utama di masa pasca perang dingin. Pertama, perbedaan peradaban tidak hanya riil, tapi juga mendasar. Selama berabad-abad perbedaan antar peradaban telah menimbulkan konflik paling keras dan paling lama. Kedua, dunia kini sudah kian menyempit sehingga interaksi antara orang yang berbeda peradaban semakin meningkat. Ketiga, peran Barat yang begitu dominan menimbulkan reaksi de-westernisasi di dunia nonBarat. Keempat, perbedaan budaya kurang bisa menyatukan, dibanding perbedaan politik dan ekonomi. Kelima, kesadaran peradaban bukanlah raiso d'etre utama terbentuknya regionalisme politik atau ekonomi. ${ }^{19}$

Sedari awal, teori benturan peradaban Huntington lebih banyak mengundang kritik, bahkan cibiran, daripada apresiasi. Selain karena dianggap sebagai fantasi yang fantastis, teori itu juga tidak mencerminkan semangat zaman yang menekankan aspek globalisasi dan pluralitas, toleransi dan kesetaraan. Lebih jauh, dengan teori tersebut, Huntington menjadi provokator perpecahan antara Islam, Yahudi dan Kristen. ${ }^{20}$

Sebenarnya menurut para ahli salah satu titik kelemahan tesis Huntington adalah kerancuan dalam mendefinisikan peradaban. Ia menyebut delapan peradaban utama yang mungkin akan saling berkonfrontasi di masa depan: Barat, Cina/Konfusius, Jepang, Islam, Hindu, Ortodoks Slavia, Amerika Latin dan mungkin juga Afrika. Di sini Huntington mencampuradukkan berbagai hal yang beraneka ragam, termasuk letak (Barat), ajaran (Konfusius), etnik (Slavia), negara (Jepang), agama (Islam) dan benua (Afrika). Terlihat jelas ia tidak konsisten dan tanpa definisi peradaban yang dapat dipakai untuk menguji tesisnya. ${ }^{21}$

Celakanya, Huntington membangun image yang sangat negatif terhadap Islam dengan menyarankan Eropa dan Amerika agar menerapkan strategi bersama untuk menghadapi ancaman-ancaman bagi masyarakat dan keamanan mereka dari militan Islam. Ia menekankan perlunya dilakukan preemptive-strike (serangan dini) terhadap kaum militan Islam. Huntington menegaskan, "Saya perlu menambahkan bahwa satu strategi yang memungkinkan dilakukannya serangan dini terhadap ancaman serius dan mendesak adalah sangat penting bagi AS dan kekuatan-kekuatan Barat saat ini. Musuh kita yang utama adalah Islam militan. ${ }^{22}$

Sejenak saja kebijakan Huntington bergulir ke seantero Amerika, William Cantwell Smith menangkap sindrom stereotip itu dengan statemen otokritiknya:

\footnotetext{
${ }^{19}$ Huntington, Benturan Peardaban...., hlm. 38-46.

${ }^{20}$ Hidayat, Wahyu Di Langit....., hlm. 11.

${ }^{21}$ Sirry, Dilema Islam ........., hlm. 243.

${ }^{22}$ Husaini, Wajah Peradaban........., hlm. 133. 
"Dalam kasus khusus menyangkut Islam, Barat mewarisi sebuah antagonisme yang berasal dari seribu tahun yang silam yang mengenainya sedikit saja orang yang mengetahui kelangsungangnya (sampai hari ini), begitu pula kedalamannya. Terhadap dunia Islam terkadang Barat ketakutan, dan selama beberapa abad terus terancam. Ketakutan dan kebencian Barat saat ini yang diekspresikan dalam bentuk anti-komunisme sudah relatif melunak dan sangat pendek masanya, dibandingkan persepsi dan emosi abad pertengahan yang anti-Islam yang berlangsung berabadabad". 23

Dengan sikap yang sangat negatif terhadap Islam, tidak berlebihan bila Murad W. Hofmann mengidentifikasi tesis Huntington tersebut mempunyai akar historis dari mental perang salib: lantaran superioritasnya yang inheren, dunia Barat telah berkembang menjadi sebuah model sah yang harus ditiru oleh seluruh dunia. Sehingga secara spesifik dari perspektif Muslim, pemikiran maupun strategi itu mengekspresikan gagasan yang khas bercorak imperialisme kultural. ${ }^{24}$ Jika dianalisis lebih dalam melalui perspektif teologis, tesis ini masih berpijak pada logika Glory (kemenangan), disamping Gold (memburu kekayaan) dan Gospel (kristenisasi). ${ }^{25}$ Semua tesis Huntington tersebut sebenarnya bukan melukiskan benturan peradaban melainkan perspektif stereotip klasik khas Barat.

\section{Membangun Dialog Peradaban}

Tanpa meremehkan perbedaan-perbedaan yang ada di antara berbagai budaya, yang perlu dikembangkan sekarang adalah proses pertumbuhan dialog lintas kultural yang didasarkan pada rasa saling menghormati dan hak untuk berbeda. Dalam konteks ini, mungkin masyarakat dunia dapat memetik hikmah pelajaran dari filsuf Muslim yang sangat diapresiasi oleh Barat, yaitu Ibn Rusyd dan teori The Harmony of Humanity yang digulirkan seorang ilmuwan Mesir abad kita, Raghib As-Sirjani sebagai antitesis dari Teori the Clash of Cilivizations. Jika Huntington menggulirkan teori yang meresahkan umat manusia tentang prediksinya akan terjadi benturan antar berbagai beradaban besar dunia, Raghib justru menyemaikan optimisme mengenai hubungan harmonis antar umat manusia berdasarkan kesamaan-kesamaan fundamental pada setiap umat manusia.

\footnotetext{
${ }^{23}$ Murad W. Hofmann, Bangkitnya Agama, terj. Abdullah Ali (Jakarta: Serambi, 2003), hlm. 8283.

${ }^{24}$ Ibid., hlm. 78.

25 Joko Suryo, Catatan Kuliah Sejarah Peradaban dan Perkembangan Agama di Barat, Yogyakarta: Uin Sunan Kalijaga, 28-02-2006.
}

56 | EDUGAMA Vol.03 No.01 Juli 2017 
Ibn Rusyd, ulama-filosof kelahiran Andalusia ini telah mengembangkan aturan dialog antar kebudayaan yang sangat relevan untuk didiskusikan. Ia membangun rules of dialogue di atas tiga prinsip epistemologis. ${ }^{26}$ Pertama, keharusan untuk memahami 'yang lain' dalam sistem referensinya sendiri. Dalam kasus Ibn Rusyd, hal ini terlihat dari penerapan metode aksiomatik dalam menafsirkan diskursus filosofis ilmu-ilmu Yunani. Ibn Rusyd berusaha melihat seluruh kebudayaan pemikiran Yunani tidak serta-merta dengan justifikasi penilaian ketimuran, tapi mencoba memandangnya melalui kerangka perspektif wacana Yunani. Pendekatan antar budaya semacam ini akan membuka cakrawala pemahaman tentang yang lain secara objektif, tidak subjektif.

Harus diakui, selama ini Barat melihat fenomena yang terjadi dalam dunia Muslim nyaris seluruhnya hanya melalui kaca mata Barat an sich. Dengan perspektif negatif dan bahkan rekayasa media massa Barat, mereka membangun kenyataan khayali bangsa Muslim yang distorsif menjadi realitas sesungguhnya di mata dunia. Karen Armstrong, seorang pakar lintas agama dewasa ini, menangkap kelicikan media massa Barat tersebut. Bagaimana media Barat mengekspos secara spektakuler dukungan umat Islam terhadap fatwa Imam Khomeini agar membunuh salman Rushdie, padahal dalam konferensi Islam tahun 1989, 44 dari 45 bangsa Muslim menolak peraturan Khomeini tersebut, merupakan bukti mengenai bias perspektif Barat yang sengaja mereka rancang. ${ }^{27}$

Tidak hanya itu, gambar-gambar komik, serial TV, film dan kartun, ikonografi Islam bersifat seragam, universal dan melalui kaca mata kuda Barat: Muslim sebagai teroris dan kelompok haus darah. Sebaliknya, hanya ada sedikit ruangan, untuk berbicara atau bahkan untuk memikirkan, apalagi menggambarkan, Islam atau apa saja yang islami secara simpatik. Hingga menurut Edward W. Said, hampir semua orang, jika diminta untuk menyebutkan nama seorang penulis Islam modern, mungkin hanya dapat menyebut Kahlil Gibran (bukan Islam) ${ }^{28}$

Tidak terkecuali para akademisi yang mengambil spesialisasi tentang keislaman pun pada umumnya memperlakukan agama Islam dan berbagai kebudayaannya berdasarkan khayalan atau berdasarkan kerangka ideologis yang telah ditentukan yang sarat dengan kemarahan dan prasangka, bahkan kadang-kadang dengan muak. Karena kerangka inilah pemahaman yang benar terhadap Islam sangat sulit dicapai. Pada titik inilah, relevansinya Barat untuk belajar memahami yang lain, khususnya Islam, melalui referensi Islam sendiri bukan

\footnotetext{
${ }^{26}$ Esposito, Dialektika Peradaban ........ hlm. 100-104; Sirry, Dilema Islam, hlm. 245-247.

${ }^{27}$ Karen Armstrong, Muhammad Sang Nabi, terj. Sirikit Syah (Surabaya: risalah Gusti, 2004), hlm. XII.

${ }^{28}$ Said, Covering......, hlm. 7.

57 | EDUGAMA Vol.03 No.01 Juli 2017
} 
ZAPRULKHAN | Membangun Dialog Peradaban

memaksakan paradigma Barat, apalagi yang sudah dimuati berbagai vested interest (kepentingan sesaat).

Kedua, prinsip selanjutnya yang kita pinjam dari Ibn Rusyd adalah menciptakan kembali hubungan yang subur antara Islam dan Barat dengan mengedepankan hak untuk berbeda. Ibn Rusyd membela pendapat bahwa tidak ada kontradiksi antara kebenaran agama dan filsafat, tapi terjadi harmoni keduanya. Harmoni tidak berarti sama dan identik, karenanya hak untuk berbeda harus dihargai. Dunia internasional hari ini mungkin harus menengok sejenak sejarah keakraban bahkan persaudaraan universal tiga agama besar: Yahudi. Kristen dan Islam di bawah payung kekuasaan umat Islam di Spanyol selama lebih dari 600 tahun pada era klasik. $^{29}$

Ketiga, mengembangkan sikap pengertian, toleransi dan partisipasi. Ibn Rusyd menolak cara Ghazali menguliti para filosof tidak dengan tujuan untuk mencari kebenaran. Ketika Ghazali mengatakan, "Tujuan saya adalah mempertanyakan tesis para filosof dan saya berhasil". Ibn Rusyd menjawab, "Ini tidak sewajarnya dilakukan oleh orang terpelajar karena tujuan orang terpelajar tak lain adalah mencari kebenaran dan bukan menyebarkan keraguan". Dengan demikian, para pembela perdamaian dunia seyogyanya memerangi keangkuhan "aku" terhadap "yang lain", karena itu hanya akan menyebarkan ketidakpercayaan (mistrust) dan menyalakan permusuhan.

Sedangkan Raghib As-Sirjani secara garis besar menyuguhkan 4 hal prinsipil yang menjadi landasan pergaulan, hubungan, dan keharmonisan umat manusia.

\section{Kategori Kesamaan Tertinggi}

Kelompok kesamaan manusia yang pertama ini hanya terdiri atas satu jenis kesamaan, yaitu akidah. Raghib menilai kesamaan yang satu ini merupakan kesamaan terpenting yang menjadi keistimewaan manusia sekaligus merupakan milik manusia yang paling berharga, dan anugerah paling utama berupa "identitas" tertentu. Akidah menjadi pengikat paling kuat antara dua individu atau dua bangsa. Ia menembus batas-batas waktu dan tempat. Pasalnya, pemeluk akidah tertentu merasa satu dengan para pemeluk akidah sama yang hidup seribu tahun sebelum mereka, sehingga mereka merasakan kesatuan sebagai penganut satu akidah yang sama, kendati berasal dari berbagai suku yang berbeda-beda. Selain itu, mereka juga merasakan kesatuan dengan para penganut akidah sama yang hidup di tempat jauh, atau hidup dalam kondisi

${ }^{29}$ Karen Armstrong, Berperang Demi Tuhan, terj. Satrio Wahono dkk. (Jakarta \& Bandung: Serambi \& Mizan, 2002), hlm. 8-11; Bandingkan dengan Nurcholish Madjid, Islam Doktrin \& Peradaban (Jakarta: Paramadina, 1995), hlm. 143-153. 
ekonomi yang sangat berbeda. Inilah pengikat paling luhur yang tiada lagi pengikat lain di atasnya. $^{30}$

Akidah adalah hal yang dimiliki bersama oleh semua manusia. Artinya, setiap orang pasti memiliki akidah. Adalah benar bahwa akidah suatu bangsa berbeda dari akidah bangsa yang lain. Namun, akidah selalu ada dalam segala keadaan, sehingga tidak seprang pun yang tidak memiliki akidah, termasuk orang-orang kafir yang mengingkari eksistensi Tuhan bagi alam semesta ini juga memiliki "akidah", yaitu bahwa Tuhan tidak ada. Mereka memiliki imajinasi dan falsafah tertentu yang dapat menjelaskan keyakinan itu. Mereka sangat fanatis dengan keyakinan mereka itu. Mereka merasa bahwa mereka berada di pihak yang benar, sementara orang lain berada di pihak yang salah. Alhasil, setiap orang-seperti apapun orang itu—pastilah memiliki akidah dan agama. Termasuk, kalaupun seandainya akidah itu adalah "tidak berakidah", termasuk seandainya agama itu adalah "tidak beragama". ${ }^{31}$

Berhubungan dengan akidah, keyakinan, atau ideologi, Raghib membagi dalam tiga kelompok besar. Pertama, adalah kelompok agama-agama Samawi, yaitu meliputi Islam, Kristen, dan Yahudi. Ketiga agama ini dianut oleh lebih dari separuh penduduk bumu (54\%). Mereka semua memiliki kesamaan dalam segala hal. Kalaupun ada - tidak diragukan lagi pasti ada - berbagai perbedaan mendasar antara ketiga keyakinan Samawi ini, sebenarnya mereka memiliki kesamaan pada hal-hal prinsip. Namun, yang penting di sini adalah menunjukkan bahwa ada beberapa pemikiran yang sama antara beberapa agama ini yang dapat menyatukan setengah penghuni bumi pada satu kesatuan! Hal ini mungkin tidak pernah diimpikan oleh seorang reformis atau filsuf mana pun. Namun, ini adalah sebuah kenyataan yang jelas.

Kelompok kedua adalah kelompok agama-agama yang disebut agama artifisial (buatan). Pemeluk agama jenis ini pun banyak. Jumlah mereka mendekati sepertiga penduduk (30\%). Yang terbanyak dari kelompok ini adalah pemeluk Hindu yang mencapai $14 \%$ dari penduduk dunia. Setelah itu, ada pemeluk agama-agama lain seperti Budha, Shinto, dan berbagai agama lokal lainnya yang tersebar di seluruh penjuru dunia.

Kelompok ketiga - yang terakhir, adalah kelompok kaum tidak beragama atau orangorang atheis yang sama sekali mengingkari keberadaan Tuhan. Jumlah mereka mendekati seperlima penduduk dunia (16\%), atau mungkin lebih dari itu. Sebab, banyak orang yang didata sebagai pemeluk Kristen di Eropa dan Amerika sebenarnya adalah atheis yang tidak mengakui agama apa pun.

${ }^{30}$ Raghib As-Sirjani, The Harmony of Humanity, terj. Fuad Syaifudin Nur, dkk (Jakarta: Pustaka Al-Kautsar, 2015), hlm.125-126.

${ }^{31}$ Ibid., hlm. 127. 
Yang terpenting, kita menemukan fakta bahwa semua umat manusia "sama-sama" memiliki akidah tertentu ihwal siapa Tuhan, apa saja sifat-sifat-Nya, bagaimana menyembahNya, dan apa yang Dia kehendaki dari kita. Juga, banyak manusia yang "meyakini" ketiadaan Tuhan. ${ }^{32}$ Dengan menyadari kesamaan tertinggi ini, setiap orang harus membangun dialog dengan menghormati dan menghargai bahwa setiap orang memiliki keyakinan, agama, dan ideologi masing-masing yang tidak boleh dipaksa untuk berubah atau memiliki keyakinan yang sama seluruhnya.

\section{Kategori Kesamaan Umum Manusia}

Kelompok kesamaan manusia yang kedua Raghib sebut dengan istilah "Kesamaan Umum Manusia", yaitu segala hal yang sama-sama dimiliki oleh seluruh manusia, baik pada bagian pokok maupun cabangnya. Sedemikian umumnya jenis kebersamaan ini, sampai-sampai kita dapat mengatakan bahwa orang yang tidak memiliki kesamaan dalam jenis ini dapat disebut bukan manusia! Ini menunjukkan bahwa kebersamaan yang satu ini memang benar-benar penting bagi kehidupan. Segala bentuk penentangan terhadapnya, baik dengan tindakan menyakiti maupun merugikan, hanya berarti perang dan konflik!.

Namun, seiring dengan itu, semua manusia dapat dengan mudah untuk berhimpun di bawah kesamaan yang satu ini, karena mereka sama-sama menghormatinya dan berupaya untuk memilikinya. ${ }^{33}$ Kesamaan umum manusia mencakup kebutuhan primer, akal, akhlak asasi, kepemilikan, kehormatan, kebebasan, ilmu pengetahuan, dan pekerjaan. Yang termasuk kebutuhan primer adalah: makanan, air, tempat tinggal, keluarga, keamanan, dan pakaian. Jika manusia tidak menemukan bebagai hal ini, secara naluriah ia berusaha mendapatkannya. Dan, kalau ada yang menghalanginya dari berbagai hal tersebut, pastilah terjadi perang atau benturan. Pasalnya, kita tidak dapat membayangkan adanya kehidupan tanpa berbagai kebutuhan primer ini. $^{34}$

Kesamaan umum manusia yang kedua adalah akal. Akal inilah yang membedakan manusia dari makhluk lainnya. Dengan akal ini, manusia bertanggung jawab atas segala tindakan dan perbuatannya. Ketiadaan akal menghilangkan taklif (pembebanan kewajiban agama) dan tanggung jawab dari manusia. Ini telah diketahui oleh setiap agama, kebiasaan, dan aturan. Tiada dosa dan tiada hisab atas seorang anak kecil yang belum matang akalnya, juga atas orang tua yang sudah pikun. Demikianlah pula yang berlaku atas orang gila yang kurang waras. Dengan begitu, akal adalah syarat taklif. Dan, karena itulah akan menjadi kebutuhan terpenting

\footnotetext{
${ }^{32}$ Ibid., hlm. 127-128

${ }^{33}$ Ibid., hlm. 134.

${ }^{34}$ Ibid., hlm. 135.
} 
manusia. Serangan terhadap akal menjadi serangan terhadap inti kemanusiaan. Dari titik ini, teori kesamaan manusia menyeru agar bangsa-bangsa bertemu pada hal-hal yang diterima oleh akal secara umum. Tidak perlu dialog ataupun perdebatan dalam berbagai hal yang tidak masuk akal secara umum. ${ }^{35}$

Kesamaan umum manusia yang ketiga adalah akhlak asasi yang meliputi jujur, amanah, dan adil. Semua bangsa di dunia menghormati dan menghargai ketiga akhlak ini, termasuk ketika mereka belum melaksanakannya. Bangsa-bangsa yang tidak menjaga nilai-nilai asasi ini pun tidak berani berterus terang bahwa mereka berbohong, berkhianat, ataupun bersikap zalim, melainkan selalu mencari pembenaran dan apologi atas perbuatan mereka. Terkadang mereka menipu orang lain lewat iklan dan propaganda guna meyakinkan bahwa mereka tidak menyimpang dari akhlak-akhlak asasi ini. Jadi, dari perspektif ini, ketiga jenis akhlak tersebut merupakan Kesamaan Umum Manusia yang dihormati oleh setiap manusia. ${ }^{36}$ Demikian pula dengan unsur-unsur kesamaan umum manusia lainnya menjadi pengikat dialog positif antara umat manusia.

\section{Kategori Kesamaan Khusus Manusia}

Kesamaan khusus manusia mencakup aspek budaya, domisili, ras, sejarah, bahasa, adat serta tradisi, aturan undang-undang, dan akhlak-akhlak luhur. Ada dua perbedaan antara kesamaan umum dan kesamaan khusus manusia. Aspek pertama adalah bahwa manusia sama pada pokok berbagai kesamaan ini, tetapi mereka berbeda-beda pada cabang-cabangnya. Artinya, manusa bersepakat pada suatu kesamaan tertentu sebagai prinsip. Namun, mereka berbeda-beda dalam cara penerapannya. Sebagai contoh, untuk menjelaskan masalah ini, Raghib memasukkan bahasa sebagai salah satu di antara kesamaan dalam kategori ini. Setiap manusia membutuhkan bahasa untuk berkomunikasi. Namun, tiap-tiap banhsa memiliki bahasa mereka masing-masing, sehingga tidak mungkin menyatukan seluruh dunia dengan satu bahasa. ${ }^{37}$

Aspek kedua adalah bahwa Kesamaan Umum Manusia bersifat naluriah dan pasti. Artinya, kita sama sekali tidak dapat hidup tanpanya. Ketika berbagai kesamaan umum itu dicabut dari seseorang, pastilah ia berbenturan dengan orang yang mencabutnya, karena tindakannya itu mengancam hidupnya. Sebab, apa yang dicabut darinya merupakan hak miliknya yang paling berharga.

\footnotetext{
${ }^{35}$ Ibid., hlm. 136-137.

${ }^{36}$ Ibid., hlm. 140.

${ }^{37}$ Ibid., hlm. 150.
} 
Sedangkan Kesamaan Khusus Manusia—dengan segala kepentingannya-lebih rendah derajatnya daripada Kesamaan Umum Manusia. Manusia masih dapat hidup tanpanya, meskipun hidupnya itu menjadi susah. Jika kesamaan khusus ini dicabut dari seseorang, pastilah ia berbenturan dengan orang yang mencabutnya, tetapi benturan itu tidak sekeras benturan akibat tercabutnya jenis-jenis kesamaan yang lebih tinggi, seperti Kesamaan Tertinggi atau Kesamaan Umum Manusia.

Hanya saja, kedua aspek perbedaan tersebut tidak menggugurkan urgensi kesamaan khusus manusia dalam mengikat berbagai bangsa di dunia. Namun, ia tidak seperti kesamaan umum manusia yang mengikat seluruh penghuni dunia. Alih-alih, kesamaan khusus manusia hanya mengikat sejumlah manusia tertentu, yang terkadang jumlahnya sedikit, sehingga tidak lebih dari satu atau dua bangsa saja, dan terkadang jumlahnya banyak, sehingga meliputi setengah penduduk bumi, misalnya. Namun, jenis kesamaan khusus ini tidak pernah meliputi seluruh umat manusia. ${ }^{38}$

\section{Kategori Kesamaan Sekunder Manusia}

Kelompok terakhir dalam teori The Harmony of Humanity adalah kategori Kesamaan Sekunder Manusia. Kesamaan manusia yang satu ini mirip dengan kesamaan khusus manusia, karena semua manusia bersepakat pada bagian pokoknya, tetapi berbeda pada bagian cabangcabangnya. Ia bukanlah hal yang harus ada dalam kehidupan manusia, tetapi ia memperbaiki taraf kehidupan dan dapat membuat manusia bahagia. ${ }^{39}$ Kesamaan sekunder manusia ini meliputi tiga hal yakni seni, olah raga, dan pariwisata.

Kendati kategori kesamaan manusia yang satu ini berada pada urutan akhir di antara kategori-kategori kesamaan manusia yang lain, dan meskipun ia memiliki nilai spiritualitas dan kejiwaan yang lebih sedikit daripada semua jenis kesamaan manusia lain yang telah Raghib paparkan (kesamaan tertinggi, kesamaan umum manusia, dan kesamaan khusus manusia), tetapi pertemuan antar bangsa pada jenis kesamaan sekunder manusia ini biasanya bertujuan yang besar. Itulah sebabnya, jenis kesamaan manusia yang satu ini mampu menyatukan begitu banyak bangsa. Bahkan, ada sebagian kesamaan sekunder manusia ini yang menjangkau seluruh dunia! Dengan begitu, ia menjadi sebuah kesamaan umum yang menjadi titik pertemuan seluruh anak cucu Adam. ${ }^{40}$

Melalui 4 kesamaan antara seluruh umat manusia di atas, Raghib mengimbau kepada semua bangsa dan negara untuk membangun dialog konstruktif dengan menjadikan 4 hal

\footnotetext{
${ }^{38}$ Ibid., hlm. 150-151.

${ }^{39}$ Ibid., hlm. 162

${ }^{40}$ Ibid., hlm. 163.
} 
kesamaan tersebut sebagai pijakan fundamental. Dialog konstruktif merupakan dialog positif yang membuahkan hasil dan yang bertujuan mengantarkan kepada terealisasinya hasil nyata yang mewakili kesamaan umat manusia, bahkan meskipun kepentingan di sini hanya sekedar mengetahui bangsa lain dan mendengarkan mereka mendefinisikan identitas diri mereka sendiri. Pada batas ini, tujuan tersebut juga merupakan kepentingan kemanusiaan. Sesungguhnya manusia adalah musuh dari apa yang tidak diketahuinya. Oleh karena itu upaya mengenal satu sama lain merupakan jaminan yang menghindarkan pihak yang berbeda menjadi musuh. Tidak bakal ada pergaulan yang sejati tanpa berlangsungnya dialog yang jujur antar bangsa. ${ }^{41}$

Satu hal yang harus dijaga dalam berdialog, setiap bangsa jangan sampai sekali-kali mengejek, menghina, dan menodai keyakinan dan agama bangsa lain. Sebab keyakinan atau agama menjadi pegangan hidup yang mudah menyulut peperangan atas nama agama. Sedangkan perang keyakinan adalah perang terburuk di dunia dan menjadi yang paling berdarah. Sebab, manusia tidak memiliki penghalang apa pun untuk kehilangan nyawa demi membela keyakinannya. Bahkan, kematian demi membela keyakinan menjadi puncak dambaan para penganut agama-agama. Oleh karena itu, kematian beberapa orang tidak dapat menjadi akhir dari perang. Perang itu hanya dapat diakhiri setelah semuanya binasa.

Oleh karena itu, hendaknya semua orang berakal di seluruh dunia menghindari meletusnya perang keyakinan dengan sekuat tenaga. Jangan sampai ada orang yang memaksa orang lain untuk mengubah agama atau keyakinannya. Sebab, pihak yang dipaksa itu memiliki hak sempurna untuk melindungi keyakinannya dalam kondisi seperti itu. Demikianlah, peperangan tidak akan pernah berhenti selama-lamanya.

Oleh karena itu, orang-orang yang mengobarkan perang seringkali menggunakannya sebagai tali kendali untuk menggerakkan bangsa-bangsa dengan dalih agama dan keyakinan. Tujuannya adalah agar mereka dapat menjamin keberlangsungan perang demi kepentingan mereka. Padahal, perang yang sebenarnya amatlah jauh dari agama. Tampaklah tidak berlebihan jika Raghib mengatakan bahwa perang yang murni berlatar agama keyakinan di dunia ini amatlah sedikit. Kebanyakan perang itu terjadi demi berbagai tujuan lain. Peperangan yang terjadi disebabkan alasan keagamaan sebenarnya hanya dilakukan untuk menggalang kekuatan orang-orang yang siap berkorban. ${ }^{42}$

Karena itulah, dalam berdialog, diharuskan saling menghormati dan menghargai pihak lain, termasuk akidah kepercayaan, kebudayaan, tradisi dan adat istiadat mereka. Tidak akan tumbuh sebuah komunikasi dialog yang tidak bisa mengupayakan sikap saling mengapresiasi.

${ }^{41}$ Ibid., hlm. 582.

${ }^{42}$ Ibid., hlm. 131-132. 
Dialog bukan sekedar tukar pikiran antara dua belah pihak atau lebih. Dialog adalah perilaku yang berlandaskan pada dasar-dasar yang akan mengolah laku tersebut menjadi proses moral dan penalaran yang konstruktif dan terkadang memang tidak berakhir dengan memaksakan salah satu pihak mengikuti pendapat pihak lain dimana kecil kemungkinan untuk mewujudkan hal tersebut. Dengan demikian, yang tidak kalah pentingnya dari hal itu adalah tercapainya sikap saling memahami dan menghargai dan kerja sama untuk memutus benang keruwetan yang menyertai ketegangan situasi akibat emosi yang memanas. ${ }^{43}$

\section{E. Epilog}

Dikatakan bahwa semua pengetahuan mengenai masyarakat manusia, dan bukan mengenai dunia alami, adalah pengetahuan historis, dan oleh karena itu, bergantung pada penilaian dan interpretasi. ${ }^{44}$ Dengan diperkuat analisis sebelumnya, maka munculnya konflik peradaban sebenarnya bukan dikarenakan elemen-elemen internal dari masing-masing peradaban itu, tapi lebih disebabkan oleh interest yang muncul disekitarnya. Sejarah menjadi saksi bahwa benturan peradaban klasik (juga deawsa ini) dalam peperangan misalnya, lebih banyak disebabkan ambisi kelompok untuk saling menafikan dan menghancurkan agar aset ekonomi dan wilayah-wilayah politik dapat dikuasai. Itulah sebenarnya muara dari semua konflik Islam-Kristen, Timur-Barat.

Padahal sejarah juga menjadi saksi bahwa tidak ada perubahan peradaban kemanusiaan tanpa disokong oleh kekuatan lain di luar dirinya. Munculnya peradaban Islam pada masa klasik misalnya, tidak terlepas dari jasa peradaban Yunani. Demikian juga peradaban Barat yang kini menghegemoni dunia juga tidak terlepas dari prestasi umat Islam pada masanya. Singkatnya, kebesaran sebuah peradaban adalah "produk bersama" kemanusiaan, meskipun ada aktor utama yang menjadi motor penggeraknya.

Dengan paradigma peradaban sebagai produk bersama kemanusiaan, maka sekarang tidak relevan lagi berbicara tentang rivalitas peradaban. Karenanya, pembicaraan tentang orientalisme dan oksidentalisme misalnya, bukan diletakkan dalam konteks penghadapan antara Barat dan Timur sebagaimana yang selama ini terjadi, tapi harus diletakkan dalam kerangka upaya untuk saling memahami satu dengan yang lain. ${ }^{45}$ Akhirnya, sudah saatnya kita semua, Barat dan Timur untuk keluar dari kungkungan nalar dan cara berpikir konfliktual seraya berupaya untuk membangun dan mendamaikan unsur-unsur peradaban yang selama ini dikonflikkan.

\footnotetext{
${ }^{43}$ Ibid., hlm. 593.

${ }^{44}$ Said, Covering ..........., hlm. 213.

${ }^{45}$ Rumadi, Masyarakat Post-Teologi (Jakarta: Gugus Press, 2002), hlm. 43-44. 64 | EDUGAMA Vol.03 No.01 Juli 2017
} 


\section{DAFTAR PUSTAKA}

As-Sirjani, Raghib. The Harmony of Humanity. Terj. Fuad Syaifudin Nur, dkk. Jakarta: Pustaka Al-Kautsar, 2015

Armstrong, Karen. Muhammad Sang Nabi. Terj. Sirikit Syah. Surabaya: risalah Gusti, 2004. Berperang Demi Tuhan. Terj. Satrio Wahono dkk. Jakarta \& Bandung: Serambi \& Mizan, 2002.

Esposito \& John O Voll. Demokrasi di Negara-Negara Muslim. Terj. Rahmani Astuti. Bandung: Mizan, 1999. (eds.). Dialektika Peradaban. Terj. Ahmad Syahidah. Yogyakarta: Qalam, 2002.

Fukuyama, Francis. The End of History and The Last Man. Terj. M. HLM. Amrullah. Yogyakarta: Qalam, 2004.

.Trust Kebijakan Sosial \& Penciptaan Kemakmuran. Terj. Ruslani. Yogyakarta: Qalam, 2002.

Hidayat, Komaruddin. Tragedi Raja Midas. Jakarta: Paramadina, 1998 Wahyu Di Langit Wahyu Di Bumi. Jakarta: Paramadia, 2003.

Hofmann, Murad W. Islam: The Alternative. Terj. Rahmani Astuti. Bandung: Pustaka Hidayah, 2002.

Bangkitnya Agama. Terj. Abdullah Ali. Jakarta: Serambi, 2003.

Huntington, Samuel P. Benturan Antar Peradaban dan Masa Depan Politik Dunia. Terj. M. Sadat Ismail. Yogyakarta: Qalam, 2005.

Husaini, Adian. Wajah Peradaban Barat. Jakarta: Gema Insani Press, 2005.

Madjid, Nurcholish. Islam Doktrin \& Peradaban. Jakarta: Paramadina, 1995.

Mahbubani, Kishore. Bisakah Orang Asia Berpikir? Terj. Salahuddien GZ. Bandung: Mizan, 2005.

Pulungan, Suyuthi. Fiqh Siyasah. Jakarta: Grafindo Persada, 2002.

Rumadi. Masyarakat Post-Teologi. Jakarta: Gugus Press, 2002.

Said, Edward W. Covering Islam. Terj. Asnawi \& Supriyanto Abdullah. Yogyakarta: Ikon Teralitera, 2002.

Sirry,Mun'im A. Dilema Islam Dilema Demokrasi. Jakarta: Gugus Press, 2002. Membendung Militansi Agama. Jakarta: Erlangga, 2003.

Sjazali, Munawir. Islam dan Tata Negara. Jakarta: UI Press, 1993.

Suryo, Joko. Catatan Kuliah Sejarah Peradaban dan Perkembangan Agama di Barat. Yogyakarta: Uin Sunan Kalijaga, 2006. 
ZAPRULKHAN | Membangun Dialog Peradaban

Tabb, William K. Tabir Politik Globalisasi. Terj. Uzair Fauzan dkk. Yogyakarta: Lafald Pustaka, 2003.

Tim Puslit IAIN Syaruf Hidayatullah. Pendidikan Kewarganegaraan, Demokrasi, HAM \& Masyrakat Madani. Jakarta: IAIN Press, 2000

Tuner, Bryan S. Runtuhnya Universalitas Sosiologi Barat. Terj. Sirojuddin Arif dkk. Yogyakarta: Ar-Ruzz, 2002. 